TeIssien DU Cros, E. (2001): Forest Genetic Resources Management and Conservation. France as a case study, Ministry of Agriculture and Fisheries, Bureau of Genetic Resources, Commission of Forest Genetic Resources, INRA DIC, Paris.

VANDEn Broeck, A. (2004): Potential gene flow from cultivated poplar into native European Black poplar (Populus nigra L.) in Belgium. PhD. Universiteit Gent, Gent.

VAN DER BEN, D. (1997): Het Zoniënwoud. Een natuurmonument en zijn geschiedenis. Lannoo, Tielt, Belgium.

VAnder MiJnsbrugGe, K. (2003): Conservation of the heritage of autochthonous woody plants in Flanders (Belgium). Scripta Botanica Belgica 24, 105-115.

VAnder MijnsbrugGe, K., E. CoArt, H. Beeckman and J. VAN Slycken (2003a): Conservation measures for autochthonous oaks in Flanders. Forest Genetics 10 207-217.

Vander Mijnsbrugge, K., A. Van den Broeck, E. Coart, R. Devreese and M. Dumortier (2003b): Bomen en struiken, pp. 37-41 in Natuurrapport 2003 edited by M. Dumortier, L. De Bruyn, H. Peymen, A. Schneiders, T. Van Daele, G. Weyembergh, D. van Straaten and E. KuIJKEN, Instituut voor Natuurbehoud, Brussels.

Vander Mijnsbrugge, K., K. Cox and J. Van Slycken, 2004: Afbakening van Vlaamse herkomstgebieden, rapport Ibw.Bb.R.2004.001, Instituut voor Bosbouw en Wildbeheer, Geraardsbergen.

WAGNeR, I. (1999): Schutz und Nutzen von Wildobst. Probleme bei der direkten Nutzung von Wildobstrelikten. Forstarchiv 70: 23-27.

Wilson, S. M., D. C. Malcolm and D. A. Rook (1999): Locating natural populations of Scottish native trees. Scottish Forestry 53(4): 215-224.

Wilson, S. M. and C. J. A. SAmuel (2004): Genetic conservation of native trees, in Forest Research Annual Report and Accounts for 2002-2003, Forestry Commission, Edinburgh.

\title{
Classification of Genus Acanthopanax in Korea and Genetic Diversity Using Allozymes
}

\author{
By M. K. HuH ${ }^{1), *)}$ and H. W. HuH
}

(Received 20 ${ }^{\text {th }}$ April 2005)

\begin{abstract}
Genus Acanthopanax is a long-lived woody species that is primarily distributed throughout Asia. Many species of this genus are regarded as medically and ecologically important. We evaluated a representative sample of the nine taxa with allozymes to estimate genetic relationships within the genus. As some Korean populations were isolated and patchily distributed, they exhibited a low level of genetic diversity. The narrow geographic ranges, artificial distribution of habitats, and small population sizes are proposed as factors contributing to low genetic diversity. Acanthopanax seoulense was similar to $A$. sessiliflorus, while a cluster of the $A$. rufinerve population is distant from any other species. $A$. senticosus is closely related to $A$. seoulense and $A$. sessiliflorus, whereas other species (A. koreanum) are more distinct from the Korean populations. Korean species are clustered together and clearly differentiated from the Chinese and Russian Acanthopanax taxa, genus Acanthopanax
\end{abstract}

Key words: Allozyme; Genetic relationships; Genus Acanthopanax.

\section{Introduction}

The genus Acanthopanax or Eleutherococcus is a genus within the subfamily Araliaceae comprising of the

1) Department of Molecular Biology, Dongeui University 995 Eomgwangno, Busanjin-gu, Busan 614-714, Korea.

*) Corresponding author: MAN KyU HuH, Tel: +82-51-890-1529, Fax: +82-51-890-1521, E-mail address: $\underline{\text { mhuh@@eu.ac.kr }}$ diploid species $(2 \mathrm{n}=54)$ and distributed mainly in northeastern Asia. Acanthopanax can be classified as narrowly adapted species because they are usually found on the subsites of several mountains, at elevations of 600 to $1.000 \mathrm{~m}$. These long-lived perennials have purple, green, and white flowers and have a bisexual and mixed mating, reproductive system with selfing or out-crossing via insect-pollination (HUH et al., 2005). Although plants grow high in the mountains on fertile soil, they are also extensively cultivated as medicinal crops. Many species of this genus are economically important for their leaves, stems, and roots which historically were used in Korea for medicine, alcoholic liquor, and beverages.

A. senticosus native to northeastern China, Korea, and Japan and is presently prescribed for medicinal use in France, Germany, Korea, and China. A. koreanum, A. chiisanensis and $A$. seoulense are native to Korea and also a traditional medicine species.

A. senticosus is sold in the United States as "Siberian Ginseng”. It is known in China as ci wu Jia. It is also a more expensive medicine than other Acanthopanax species. Siberian Ginseng has been used for bronchitis, heart ailments, and rheumatism, and as a tonic to restore vigor, improve general health, restore memory, promote healthy appetite, and increase stamina (FosTER, 1996).

East Asian regions such as China, Korea, Japan and Russia are well known for various Acanthopanax species (LEE, 1997). The genus Acanthopanax is comprised of 
about 5 7 species in Korea. The taxonomy of Acanthopanax is based mainly on morphological characteristics. However their characteristics sometimes have limited usefulness in resolving species identification.

Typical populations of many Acanthopanax species except A. sessiliflorus are small and distributed in patches. The main concern of persistence of Acanthopanax is continued habitat destruction and fragmentation. Consequently, wild Acanthopanax are in decline and populations are fragmented by human activities such as over-gathering medicinal plants. Thus Insights into the relative gene diversity among and within wild accessions of Acanthopanax would be useful in plant breeding and also for the development of strategies for ex situ conservation of plant genetic resources (BARTISH et al., 2000).

Information on genetic variation and population structure is critical to the conservation of threatened taxa (Holsinger and GotTlieb, 1991; Thompson, 1999). Genetic analyses can provide valuable insights into the process influencing extinction, while genetic data are used to define units for conservation management and for inferring changes in population structure and dynamics (MORITz, 1995; NEWTON et al., 1999).

Although it is important to gain knowledge of the genetic variation for conservation purposes, detailed information on the levels and distribution of this variation, as well as population structure, are not available for most woody taxa in Korea (HuH et al., 2005). Therefore, the objectives of this study were to estimate how much genetic diversity is maintained in genus Acanthopanax and to describe how species-specific markers, which may be useful in germplasm classification are distributed among species.

\section{Materials and Methods}

\section{Plant materials}

All of the 17 populations were collected from nine taxa in Korea, China and Russia (Table 1). The plant materials consisted of various accessions belonging to eight species and one variety of the genus Acanthopanax. One young leaf per mature tree ( $\geq 5 \mathrm{yr}$ ) was sampled. Fifteen plants were randomly collected from each population. In addition, two species of the same family Araliaceae, Kalopanax pictus and Panax ginseng were provided for the outgroups and used to compare the phylogenetic relationship.

\section{Allozyme analysis}

The procedures used for homogenization, starch gel electrophoresis, and enzyme assay were those described by SoLTis et al. (1983). Leaves were homogenized by mechanical grinding to release enzymes from the cellular and organellar membranes, using a Tris- $\mathrm{HCl}$ grinding buffer-PVP solution (WENDEL and WEEDEN, 1989). Electrophoresis was performed with an $11.5 \%$ starch gel. Enzyme systems were assayed glutamate oxaloacetate transaminase (GOT) and shikimate dehydrogenase (SKD) were resolved on System 7 (SolTis et al., 1983); fluorescent esterase (EST), acid phosphatase
Table 1. - Codes and locations of the genus Acanthopanax and the outgroups in this study.

\begin{tabular}{lll}
\hline Species & Code & Localities \\
\hline Acanthopanax & SES101 & Mt. Seolack, Kangwon Prov., Korea \\
sessiliflorus & SES111 & Suwon, Gyeongki Prov., Korea \\
A. senticosus & SEN204 & Mt. Hack, Kangwon Prov., Korea \\
& SEN241 & Gongju, Chungcheong Prov., Korea \\
A. senticosus & for. SEN301 & Mt. Taeback, Kangwon Prov., Korea \\
inermis & SEN302 & Mt. Soback, Kangwon Prov., Korea \\
A. koreanum & KOR415 & Yangsan, Gyeongsangnam Prov. \\
& KOR406 & Masan, Gyeongsangnam Prov. \\
A. chiisanensis & CHI511 & Suwon, Gyeongki Prov., Korea \\
A. rufinerve & CHI502 & Mt. Giri, Gyeongsangnam Prov., Korea \\
A. seoulense & RUF601 & Mt. Taeback, Kangwon Prov., Korea \\
A. siebolianum & RUF602 & Mt. Odae, Kangwon Prov., Korea \\
A. gracilistylus & SEO701 & Mt. Bukhan, Seoul Prov., Korea \\
Kalopanax pictus & SEO702 & Wonju, Kangwon Prov., Korea \\
\hline & COR81 & Changchun, China \\
\hline
\end{tabular}

(ACP), leucine aminopeptidase (LAP), and peroxidase (PER), on System 9; and isocitrate dehydrogenase (IDH), glucose phosphate isomerase (PGI), malate dehydrogenase $(\mathrm{MDH})$, 6-phosphogluconate dehydrogenase (PGD), and phosphoglucomutase (PGM), on System 10.

\section{Statistical analyses}

Enzymatic data were based on allele and genotype frequencies in each accession. A locus was considered polymorphic if two or more alleles were detected, and the frequency of the most common allele was less than 0.99 . Several standard genetic parameters were estimated using a computer program developed by M. D. LOVELESS and A. F. Schnabel (Edwards and Sharitz, 2000). The percentage of polymorphic loci $(P)$ ( $P_{\mathrm{p}}$ for population level and $P_{\mathrm{s}}$ for species level), mean number of alleles per locus $(A)$, effective number of alleles per locus $\left(A_{\mathrm{E}}\right)$, number of alleles per polymorphic locus $\left(A_{\mathrm{P}}\right)$, and gene diversity $\left(H_{\mathrm{E}}\right)$ were estimated from the data. Observed heterozygosity $\left(H_{\mathrm{O}}\right)$ was compared with the HardyWeinberg expected value using Wright's fixation index $(F)$ (Wright 1965). These indices were tested for deviation from zero by $\chi^{2}$-statistics following LI and HoRviTZ (1953). NEI's gene diversity formulae $\left(H_{\mathrm{T}}, H_{\mathrm{S}}, D_{\mathrm{ST}}\right.$, and $G_{\mathrm{ST}}$ ) were used to evaluate genetic diversity within and among populations (NEI, 1973). The $G_{\mathrm{ST}}$ coefficient corresponds to the relative amount of differentiation among populations. In addition, $\chi^{2}$-statistics were used to detect significant differences in allele frequencies among populations for each locus (WORKMAN and NISWANDER, 1970). NEI's genetic identity (I) (NEI, 1973) was calculated for each pairwise combination of populations. A phylogenetic tree was constructed by the neighborjoining (NJ) method (SAITOU and NEI, 1987) using the NEIGHBOR program in PHYLIP version 3.57 (FELSENSTEIN, 1993). The genetic structure within and among populations was also evaluated using Wright's (1965) F-statis- 
tics, $F_{\text {IT }}, F_{\text {IS }}$ and $F_{\text {ST }}$. The $F_{\text {IT }}$ and $F_{\text {IS }}$ coefficients measure excesses of homozygotes relative to the panmictic expectations in the entire samples and within populations, respectively. Deviations of $F_{\text {IT }}$ and $F_{\text {IS }}$ from zero were tested using $\chi^{2}$-statistics (LI and HoRvITZ, 1953). In the context of multiallelic loci $F_{\mathrm{ST}}$ is denoted as $G_{\mathrm{ST}}$ (NEI, 1973). The estimate of $N m$ (the number of migrants per generation) was based on $G_{\mathrm{ST}}$ (SLATKIN and BARTON, 1989).

\section{Results}

The level of genetic variation was high in 17 populations of Acanthopanax (Table 2). Eleven of 23 loci $(47.8 \%)$ showed polymorphism in at least one species, while the remaining twelve (Acp-1, Acp-3, Est-2, Got, Idh-1, Lap-1, Lap-2, Mdh-2, Per-3, Per-4, Pgd-2, and Pgi-1) were monomorphic in all species. An average of $34.0 \%$ of the loci was polymorphic within species, with individual-accession values ranging from 13.0 to $47.8 \%$. The majority of the polymorphic loci expressed two (Est1, Mdh-1, Skd, Acp-2, Per-1, Per-2, Pgi-2, Pgm-1, and Pgm-2) or three alleles (Idh-2 and Pgd-1).

Across accessions, the average number of alleles per locus $(A)$ was 1.36 , ranging from 1.13 to 1.57 (Table 2). The effective numbers of alleles per locus at the species $\left(A_{\mathrm{es}}\right)$ and the accession levels $\left(A_{\mathrm{ep}}\right)$ were 1.25 and 1.15 , respectively. Numbers of alleles per polymorphic locus $\left(A_{\mathrm{p}}\right)$ were 2.05 across accessions, varying from 2.00 to 2.44. Mean genetic diversity within accessions was 0.096. In particular, the accession SES101 had the highest expected diversity (0.168); accession GRA901, the lowest (0.028).

Table 2. - Allozyme variation within 17 populations of Acanthopanax. Percentage of polymorphic loci $(P)$, mean number of alleles per polymorphic locus $\left(A_{p}\right)$, mean number of alleles per locus $(A)$, effective number of alleles per locus $\left(A_{\mathrm{e}}\right)$, observed heterozygosity $\left(H_{\mathrm{op}}\right)$, and Hardy-Weinberg-expected heterozygosity or genetic diversity $\left(H_{\mathrm{ep}}\right)$. Population locations depicted in Table 1.

\begin{tabular}{lllllll}
\hline Population & $P_{\mathrm{p}}$ & $A$ & $A_{\mathrm{p}}$ & $A_{\mathrm{e}}$ & $H_{\mathrm{op}}(\mathrm{SD})$ & $H_{\mathrm{ep}}(\mathrm{SD})$ \\
\hline SES101 & 47.8 & 1.57 & 2.18 & 1.29 & $0.129(0.013)$ & $0.168(0.041)$ \\
SES111 & 47.8 & 1.52 & 2.09 & 1.22 & $0.114(0.012)$ & $0.142(0.036)$ \\
SEN204 & 47.8 & 1.52 & 2.09 & 1.18 & $0.097(0.012)$ & $0.123(0.032)$ \\
SEN241 & 47.8 & 1.52 & 2.44 & 1.16 & $0.093(0.011)$ & $0.112(0.030)$ \\
SEN301 & 39.1 & 1.43 & 2.11 & 1.19 & $0.097(0.011)$ & $0.120(0.035)$ \\
SEN302 & 39.1 & 1.43 & 2.11 & 1.21 & $0.103(0.012)$ & $0.127(0.036)$ \\
KOR415 & 39.1 & 1.43 & 2.11 & 1.19 & $0.098(0.011)$ & $0.127(0.035)$ \\
KOR406 & 38.9 & 1.43 & 2.11 & 1.21 & $0.101(0.012)$ & $0.135(0.036)$ \\
CHI511 & 34.8 & 1.35 & 2.00 & 1.16 & $0.089(0.011)$ & $0.107(0.033)$ \\
CHI502 & 34.8 & 1.35 & 2.00 & 1.13 & $0.072(0.010)$ & $0.086(0.030)$ \\
RUF601 & 34.8 & 1.35 & 2.00 & 1.12 & $0.072(0.010)$ & $0.085(0.028)$ \\
RUF602 & 30.4 & 1.30 & 2.00 & 1.13 & $0.066(0.009)$ & $0.082(0.030)$ \\
SEO701 & 21.7 & 1.22 & 2.00 & 1.08 & $0.041(0.008)$ & $0.052(0.024)$ \\
SEO702 & 21.7 & 1.22 & 2.00 & 1.06 & $0.034(0.007)$ & $0.040(0.020)$ \\
COR801 & 17.4 & 1.17 & 2.00 & 1.07 & $0.043(0.008)$ & $0.049(0.024)$ \\
COR802 & 21.7 & 1.22 & 2.00 & 1.07 & $0.036(0.007)$ & $0.045(0.023)$ \\
GRA901 & 13.0 & 1.13 & 2.00 & 1.04 & $0.019(0.005)$ & $0.028(0.018)$ \\
Mean & 34.0 & 1.36 & 2.05 & 1.15 & 0.077 & 0.096 \\
SD & 2.33 & 0.14 & 0.06 & 0.07 & 0.002 & 0.007 \\
\hline
\end{tabular}

Table 3. - Estimates of genetic diversity statistics and 11 polymorphic loci in Acanthopanax. Total genetic diversity $\left(H_{\mathrm{T}}\right)$; genetic diversity within populations $\left(H_{\mathrm{S}}\right)$, and among populations $\left(D_{\mathrm{ST}}\right)$; deviations of genotype frequencies from HardyWeinberg expectations over all populations $\left(F_{\mathrm{IT}}\right)$, and within individual population $\left(F_{\mathrm{IS}}\right)$; and proportion of total genetic diversity partitioned among populations $\left(G_{\mathrm{ST}}\right)$.

\begin{tabular}{lrrrrrr}
\hline Locus & $H_{\mathrm{T}}$ & $H_{\mathrm{S}}$ & $D_{\mathrm{ST}}$ & $F_{\mathrm{IS}}$ & $F_{\mathrm{IT}}$ & $G_{\mathrm{ST}}$ \\
\hline Est-1 & 0.396 & 0.394 & 0.002 & 0.167 & 0.172 & 0.006 \\
Per-1 & 0.065 & 0.055 & 0.009 & 0.291 & 0.391 & $0.142^{* *}$ \\
Per-2 & 0.301 & 0.270 & 0.030 & 0.208 & 0.288 & 0.101 \\
Pgd-1 & 0.363 & 0.330 & 0.033 & 0.178 & 0.253 & 0.091 \\
Idh-2 & 0.235 & 0.222 & 0.013 & 0.232 & 0.276 & 0.057 \\
Mdh-1 & 0.045 & 0.042 & 0.003 & 0.046 & 0.113 & 0.071 \\
Skd & 0.244 & 0.227 & 0.017 & 0.247 & 0.301 & 0.071 \\
Acp-2 & 0.226 & 0.249 & 0.007 & 0.233 & 0.255 & 0.029 \\
Pgi-2 & 0.152 & 0.135 & 0.017 & 0.187 & 0.278 & $0.112^{*}$ \\
Pgm-1 & 0.165 & 0.154 & 0.011 & 0.208 & 0.259 & 0.065 \\
Pgm-2 & 0.233 & 0.229 & 0.004 & 0.151 & 0.167 & 0.019 \\
Mean & 0.223 & 0.210 & 0.014 & 0.195 & 0.250 & 0.069 \\
\hline
\end{tabular}

$* \mathrm{p}<0.05 ; * * \mathrm{p}<0.01$

$F_{\text {IS }}$, a measure of the deviation from random mating within the nine species, was 0.195 , ranging from 0.046 for Mdh-1 to 0.291 for Per-1 (Table 3). The observed significant and positive $F_{\text {IS }}$ value (0.195) indicated a significant deficit of heterozygotes in the species.

Total genetic diversity values $\left(H_{\mathrm{T}}\right)$ varied between $0.045(M d h-1)$ and 0.396 (Est-1), for an average over all polymorphic loci of 0.223 (Table 3). Interlocus variation in the within-accession genetic diversity $\left(H_{\mathrm{S}}\right)$ was high (0.210). On a per-locus basis, the proportion of total genetic variation due to differences among accessions $\left(G_{\mathrm{ST}}\right)$ ranged from 0.006 for Est-1 to 0.142 for Per-1, with a mean of 0.069 . This indicated that about $6.9 \%$ of the total allozyme variation was among species. The estimate of gene flow, based on $G_{\mathrm{ST}}$, was slightly high among accessions of Acanthopanax $\left(N_{m}=0.069\right)$. Values of genetic distance (D) were $<3.159$. Genetic identity values among pairs of accessions ranged from 0.336 to 0.994 .

Our analysis of fixation indices, calculated for all polymorphic loci in each accession, showed a slight deficiency of heterozygotes relative to Hardy-Weinberg expectations (Table 4). For example, most fixation indices were positive (110/130), of which 16 indices $(14.5 \%)$ departed significantly from zero $(p<0.05)$. In contrast, of 20 negative indices, none was significant from zero $(P>0.05)$.

Adh-2-a allele can be recognized as unique allele of A. sessiliflorus and it is not found in any other species. Differences of allelic frequencies for other alleles are also existed among species (data not shown).

Clustering of Acanthopanax accessions, using NJ, was performed based on genetic distances (Fig. 1). The dendrogram showed several distinct groups. Although many accessions were well separated from each other, this tree also did not reveal any genetic differentiation among accessions for either $A$. senticosus or A. senticosus for. inermis. 
Table 4. - Wright's fixation indices for 17 populations of Acanthopanax using allozyme analyses.

\begin{tabular}{lccccccccccc}
\hline Accession & Est-1 & Per-1 & Per-2 & Pgd-1 & ldh-2 & Mdh-1 & Skd & Acp-2 & Pgi-2 & Pgm-1 & Pgm-2 \\
\hline SES101 & 0.173 & 0.252 & 0.185 & 0.226 & 0.236 & -0.051 & $0.346^{*}$ & $0.464^{* *}$ & 0.163 & 0.283 & 0.216 \\
SES111 & 0.083 & $0364^{*}$ & 0.159 & 0.182 & 0.274 & -0.100 & $0.363^{*}$ & 0.205 & 0.250 & 0.202 & 0.208 \\
SEN204 & 0.020 & 0.269 & 0.324 & 0.137 & 0.331 & -0.036 & $0.408^{* *}$ & 0.292 & 0.250 & 0.234 & 0.131 \\
SEN241 & 0.140 & $0.356^{*}$ & 0.260 & 0.050 & -0.026 & 0.276 & 0.220 & 0.198 & 0.163 & 0.198 & 0.202 \\
SEN301 & 0.105 & - & 0.253 & 0.146 & - & - & 0.216 & 0.228 & 0.331 & 0.149 & 0.292 \\
SEN302 & 0.185 & - & 0.263 & 0.227 & 0.327 & - & 0.163 & -0.047 & 0.271 & 0.181 & 0.100 \\
KOR415 & 0.208 & - & 0.208 & 0.272 & 0.271 & - & $0.381^{*}$ & 0.307 & 0.036 & 0.272 & 0.181 \\
KOR406 & 0.233 & - & $0.375^{*}$ & 0.270 & 0.324 & - & 0.243 & 0.244 & 0.084 & $0.357^{*}$ & 0.288 \\
CHI511 & 0.208 & - & 0.065 & -0.054 & 0.288 & - & 0.115 & 0.181 & - & $0.385^{*}$ & 0.113 \\
CHI502 & 0.065 & - & 0.171 & 0.207 & -0.038 & - & $0.369^{*}$ & 0.149 & $0.473^{* *}$ & - & -0.054 \\
RUF601 & 0.171 & - & 0.075 & 0.229 & 0.267 & - & -0.054 & 0.335 & - & -0.017 & 0.100 \\
RUF602 & 0.190 & - & 0.302 & - & -0.056 & - & -0.016 & 0.311 & - & -0.035 & 0.105 \\
SEO701 & 0.253 & - & - & - & $0.367^{*}$ & - & 0.163 & -0.047 & - & - & -0.036 \\
SEO702 & 0.253 & - & - & - & $0.344^{*}$ & - & - & -0.024 & - & -0.035 & -0.066 \\
COR801 & 0.128 & - & - & - & 0.205 & - & - & 0.090 & - & - & 0.149 \\
COR802 & 0.196 & - & - & - & -0.024 & - & - & 0.283 & - & -0.016 & $0.358^{*}$ \\
GRA901 & $0.381^{*}$ & - & - & - & - & - & - & - & - & - & 0.272 \\
\hline
\end{tabular}

Note: A dash indicates fixed loci. $* \mathrm{p}<0.05 ; * * \mathrm{p}<0.01$.

\section{Discussion}

In allozyme analysis, nine species belonging to genus Acanthopanax maintain a lower than average level of genetic diversity compared with other plant species (HAMRICK and GoDT, 1989). For example, its genetic

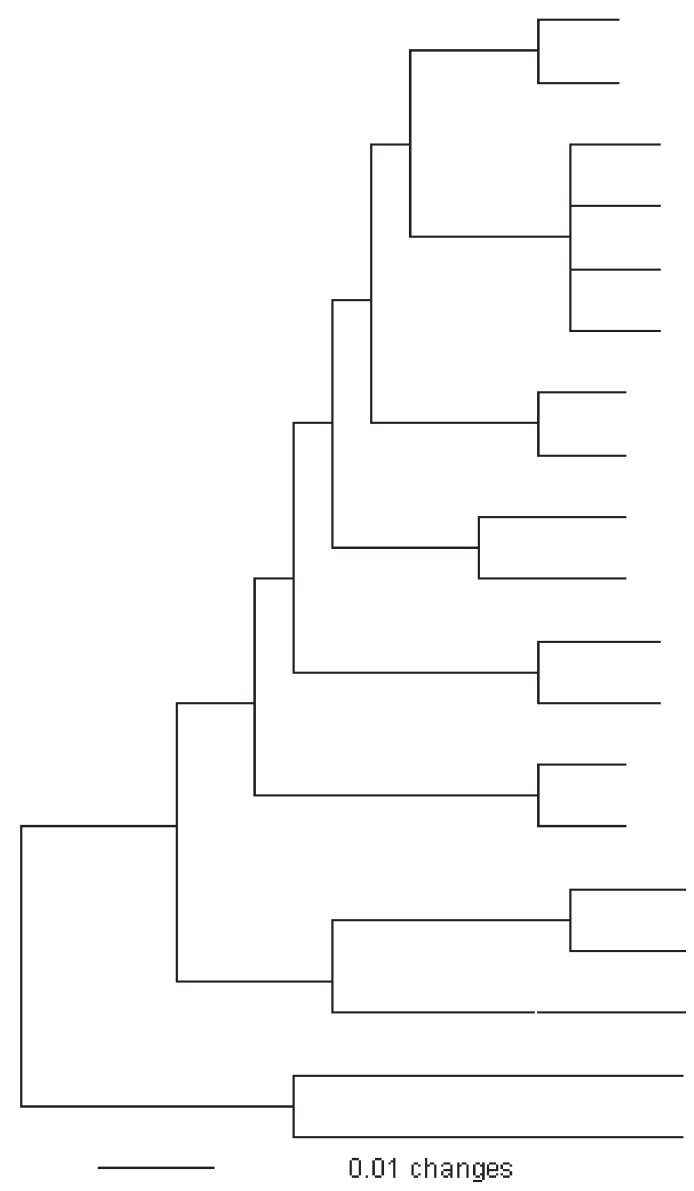

SES101

SES111

SEN204

SEN241

SEN301

SEN 302

$\mathrm{CH} 511$

$\mathrm{CH} 502$

KOR 415

KOR 406

SEOT01

$\mathrm{SEOT02}$

RUF601

RUF602

COR801

$\mathrm{CORBO2}$

GRA901

KAL100

PAN100

Figure 1. - A phylogenetic tree for Acanthopanax based on allozyme analysis. diversity of 0.096 is lower than that for temperate-zone species (0.146), dicots (0.136), species with a sexual reproduction mode $(0.151)$, and those with a long-lived woody habit (0.177) (HAMRICK and GODT, 1989). The percentage of polymorphic loci at the species level for Acanthopanax is $34.0 \%$, which is also lower than that for species with temperature-zone distributions (48.5\%), dicots $(44.8 \%)$, species with a sexual reproduction mode $(51.6 \%)$, and long-lived and woody $(64.7 \%)$ (HAMRICK and GoDT, 1989).

A striking feature of this study is the lacking of intrapopulations variation. Only $6.9 \%$ variation was found among populations and about $93.1 \%$ within populations. The Korean populations were less differentiated than other insect or wind-pollinated outcrossing species (HAMRICK et al., 1992).

Common life history traits, such as wind dispersal or animal dispersal of both pollen grains and seeds, reproductive capability, similar longevity and successional behavior, could more readily account for most of the homology in the population genetics of these species, and most likely for the low differentiation observed at the intraspecific (LOVELESS and HAMRICK, 1984).

Geographic range has been shown to be strongly associated with the level of variation maintained both within populations and at the species level (THOMPSON, 1999). Widely distributed species tend to maintain more variation than the more narrowly distributed species level (LOVELESS and HAMRICK, 1984; HAMRICK and GODT, 1989). For all Korean Acanthopanax taxa where the number of alleles per polymorphic loci was calculated, relatively widespread species (A. sessiliflorus and $A$. senticosus) had more alleles than restricted species (A. koreanum, A. chiisanensis, and A. rufinerve). In addition, effective population sizes also have an important role in maintaining genetic diversity. The periodical cutting of branches and stems has often been moved from hillside to nearby farmhouses for the purpose of medicine during the past several decades. Small populations tend to have 
fewer multilocus genotypes and genetic diversity than large populations. If Acanthopanax is self-compatible, smaller populations probably exhibit more selfing than larger populations by virtue of the limited opportunities for outcrossing during any flowering season. Considering the small and isolated populations observed in Acanthopanax, probable mating among relatives via localized pollinator behavior rather than self-pollinating occurs within these populations. Such structure can lead to biparental inbreeding or sib-mating, causing heterozygote deficiencies.

A substantial heterozygote deficiency in some populations and at some loci $\left(F_{\text {IS }}=0.195\right)($ Table 3$)$. The patch distribution of related individuals should generate a Wahlund effect. Our sampling included individuals from several patches per population, resulting in an overall deficiency of heterozygotes. It is probable that the combination of these factors may contribute to heterozygote deficiencies within these populations (Table 3).

$A$. senticosus and $A$. senticosus for. inermis were morphologically distinguished from each other. One of the most striking features between both taxa were the sharp and stiff spines (or thorns) growing along the stem. A. senticosus is covered with many spines, whereas $A$. senticosus for. inermis is thornless. Three species (A. koreanum, A. seoulense and A. rufinerve) from Korea formed another group in allozyme markers. A. koreanum was closely related to the populations from the southern part of the coast of the Korean Peninsula. A. rufinerve has many hairs on leaves. A. chiisanensis is most closely related to $A$. senticosus. Thus this species is considered a sister species of $A$. senticosus.

By current categories for threatened taxa in Korea, almost all species belonging to genus Acanthopanax should be considered threatened. The probability of extinction of any single population is high, since the populations of natural A. senticosus are so small. Ecological management of these populations will be necessary to preserve the species. Many other populations of Acanthopanax as well as $A$. senticosus are declining in population size because of habitat loss from harvesting for medicinal purposes. Populations showing the highest genetic diversity by allozymes could be recommended for in-situ conservation.

\section{Acknowledgments}

This work was partly supported by Korean Research Foundation Grant (KRF-2003-2003-C00250).

\section{References}

Bartish, J. V., N. Jeppson, G. I. Bartish, R. LU and H. Nyвом (2000): Inter- and intraspecific genetic variation in Hippophae (Elaeagnaceae) investigated by RAPD markers. Plant Syst. Evol. 225: 85-101.

EDWARDS, A. L. and R. R. SHARITZ (2000): Population genetics of two rare perennials in isolated wetlands: Sagittaria isoetiformis and S. teris (Alismataceae). Am. J. Bot. 87: 1147-1158.

FeLsenstein, J. (1993): PHYLIP (Phylogeny Inference Package) version 3.5s. Distributed by the author. Department of Genetics, Univ. Washington, Seattle.
Foster, S. (1996): Siberian Ginseng-Eleutherococcus senticosus. Botanical Booklet Series, No 302. Austin: American Botanical Council.

HAMRICK, J. L. and M. J. W. GoDT (1989): Allozyme diversity in plant species, pp. 304-319 in Plant population genetics, breeding and genetic resources, edited by A. H. D. Brown, M. T. ClegG, A. L. Kahler, B. S. Weir, Sinauer Associates, Sunderland/MA.

Hamrick, J. L., M. J. W. Godt and S. L. Sherman-Broyles (1992): Factors influencing levels of genetic diversity in woody plant species. New Forests 6: 95-124.

Holsinger, K. E. and L. D. GotTLIEB (1991): Conservation of rare and endangered plants: Principles and prospects, pp. 195-223 in Genetics and conservation of rare plants, edited by D. A. FALK, K. E. Holsinger, Oxford University Press.

HuH, M. K. (1999): Genetic diversity and population structure of Korean Alder (Alnus japonica : Betulaceae). Can. J. For. Res. 29: 1311-1316.

HuH, M. K., H. W. HuH and K. BACK (2005): Genetic diversity and population structure of Korean Acanthopanax sessiliflorus (Araliaceae) using AFLP. Korean J. Genet. 27: 71-79.

LEE, Y. N. (1997): Flora of Korea. Kyo-Hak Publishing Co, Seoul, Korea.

LI, C. C. and D. G. Horvitz (1953): Some methods of estimating the inbreeding coefficient. Am. J. Hum. Genet. 5: $107-117$.

Loveless, M. D. and J. L. HAMrick (1984): Ecological determinants of genetic structure in plant populations. Ann. Rev. Ecol. System. 15: 65-95.

MoRITZ, C. (1995): Uses of molecular phylogenies for conservation. Philosophical Transactions of the Royal Society of London Series B: Biol. Sci. 349: 113-118.

NEI, M. (1973): Analysis of gene diversity in subdivided populations. Proc. Natl. Acad. Sci. USA 70: 3321-3323

Newton, A. C., T. Allnutt, A. C. M. Gillies, A. Lowe and R. A. Ennos (1999): Molecular phylogeography, interspecific variation and the conservation of tree species. Trends Ecol. Evol. 14: 140-145.

SAItou, N. and M. NEI (1987): The neighbor-joining method: A new method for reconstructing phylogenetic trees. Mol. Biol. Evol. 4: 406-425.

Slatkin, M. and N. H. Barton (1989): A comparison of three indirect methods for estimating average levels of gene flow. Evolution 43: 1349-1368.

Soltis, D. E., C. H. Haufler, D. C. Darrow and G. J. GASTONY (1983): Starch gel electrophoresis of ferns: A compilation of grinding buffers, gel and electrode buffers, and staining schedules. Am. Fern J. 73: 9-27.

ThOMPSON, J. D. (1999): Population differentiation in Mediterranean plants: insight into colonization history and the evolution and conservation of endemic species. Heredity 82: 229-236.

WENDEL, J. F. and N. F. WEEDEN (1989): Visualization and interpretation of plant isozymes, pp. 5-45 in Isozymes in plant biology, edited by D. E. Soltis and P. S. SolTis, Chapman and Hall, London.

Workman, P. L. and J. D. Niswander (1970): Population studies on southern Indian tribes. II. local genetic differentiation in the Papago. Am. J. Hum. Genet. 22: 24-49.

WRIGHT, S. (1965): The interpretation of population structure by $F$-statistics with special regard to systems of mating. Evolution 19: 395-420. 